\title{
POLITIKK
}

\section{Norges vern av suverene rettigheter rundt Svalbard: Russiske persepsjoner og reaksjoner}

\author{
Anne-Kristin Jørgensen og Andreas Østhagen * \\ Fridtjof Nansens institutt
}

\begin{abstract}
Sammendrag
Svalbard og vernesonen rundt øygruppen står sentralt i det bilaterale forholdet mellom Norge og Russland, både økonomisk og sikkerhetspolitisk. Siden 1977 har en konflikt mellom landene omhandlet Norges rett til myndighetsutøvelse i disse farvannene. Hva er russiske persepsjoner av norsk politikk i vernesonen? Hvordan har persepsjoner og reaksjoner utviklet seg siden årtusenskiftet? Hvilke endringer - om noen - ser vi i forbindelse med forverringen i det bilaterale forholdet etter 2014? Og hva betyr dette for faren for en eventuell konflikt i dette området? Oppsummert finner vi at 2014 ikke fremstår som noe vannskille med hensyn til forholdet mellom Norge og Russland i vernesonen. Den store endringen kom da de russiske føderale myndighetene fra og med «Elektron»-saken i 2005 gikk over fra protest til dialog. Siden har Russland lagt seg på en relativt forsonlig linje. Unntaket er en kort periode etter arrestasjonen av den russiske tråleren "Sapfir-2» i etterkant av delelinjeavtalen mellom Norge og Russland fra 2010, da store deler av rederinæringen og andre i det russiske nord var i harnisk og krevde handling angående vernesonen. Etter 2011 har hendelser i vernesonen blitt håndtert uten ytterligere eskalering. Dette er derimot ikke en naturtilstand, men en situasjon underbygd av en rekke spesifikke faktorer som kan komme til å endre seg.
\end{abstract}

Nøkkelord: Fiskevernsonen $\cdot$ Svalbard $\cdot$ Russland $\cdot$ kystvakt $\cdot$ nordområdene

\footnotetext{
^Kontaktinformasjon: Andreas Østhagen, e-post: ao@fni.no

(C2020 Anne-Kristin Jørgensen og Andreas Østhagen. This is an Open Access article distributed under the terms of the Creative Commons Attribution 4.0 International License (http://creativecommons.org/licenses/by/4.0/), allowing third parties to copy and redistribute the material in any medium or format and to remix, transform, and build upon the material for any purpose, even commercially, provided the original work is properly cited and states its license. Citation: Anne-Kristin forgensen og Andreas Østhagen (2020). Norges vern av suverene rettigheter rundt Svalbard: Russiske persepsjoner og reaksjoner, Internasjonal Politikk, 78(2): 167-192. http://dx.doi.org/10.23865/intpol.v78.1838
} 


\section{Introduksjon $^{1}$}

Norges havområder er syv ganger større enn Norges landmasse. Fiskevernsonen rundt Svalbard (heretter: vernesonen) utgiør en betydelig andel av disse områdene. Norge opprettet denne sonen i 1977 for å verne om de suverene rettighetene som Norge, i likhet med andre kyststater, hadde ervervet som følge av endringer i havretten. Sovjetunionen hevdet imidlertid at Norge ikke hadde folkerettslig hjemmel for å opprette en slik sone, da dette ikke var spesifisert i Svalbardtraktaten fra 1920. Dette er også Russlands posisjon i dag.

Selv om Norge og Russland har felles interesser og et ønske om å bevare ro og stabilitet i disse havområdene, er det ikke gitt at forholdet alltid vil være konfliktfritt. Spesielt $\mathrm{i}$ interaksjoner med russiske fiskefartøy i vernesonen ligger det et konfliktpotensial, med bakgrunn i de nevnte motsetningene mellom norsk og russisk syn på statusen til denne maritime sonen. I tillegg er det både i Norge og i NATO en økt oppmerksomhet om Nord-Atlanteren og Barentshavet som et av områdene hvor Russlands militære satsing det siste tiåret gjør seg gjeldende. Dette ble understreket av uttalelsen fra Russland til Norge i forbindelse med 100-årsmarkeringen av Svalbardtraktaten i februar 2020, hvor Russland utenriksminister Lavrov legger vekt på at vernesonen er rettsstridig. ${ }^{2}$

Gitt betydningen av Svalbard i nordområdene er det viktig å forstå russiske tilnærminger til dette temaet. Vi spør derfor: Hva er russiske persepsjoner av norsk politikk i vernesonen? Hvordan har persepsjoner og reaksjoner utviklet seg etter at den norske Kystvakten rundt årtusenskiftet strammet inn sin håndhevingspraksis i sonen? Hvilke endringer - om noen - ser vi i forbindelse med forverringen i det bilaterale forholdet etter 2014? Og hva betyr dette for faren for en eventuell konflikt i dette området?

Tidligere forskning tilsier at det vil være for enkelt å ta utgangspunkt i Russland som en enhetlig aktør når vi søker å besvare disse spørsmålene. I en analyse av det russiske reaksjonsmønsteret etter Kystvaktens arrestasjoner av trålerne "Tsjernigov» (2001) og "Elektron» (2005) i vernesonen registrerte for eksempel Bruusgaard (2006) at sterke, sentrale aktører begge ganger var tilhengere av mer moderate (diplomatiske) reaksjoner enn svakere, regionale aktører, og at de som sto for en mer "radikal» linje, var blitt svekket i 2005 i forhold til i 2001.

Siden den tid har den relativt mer moderate sentralmakten i Russland blitt ytterligere styrket i forhold til regionene og sektorinteressene. I seg selv skulle dette tilsi færre forsøk på å utfordre norsk myndighetsutøvelse - i hvert fall i form av soloutspill fra

\footnotetext{
${ }^{1}$ Vi vil rette en spesiell takk til kollega Arild Moe for gjennomlesning, innspill og kommentarer i arbeidet med denne artikkelen. I tillegg vil vi takke fagfellene for verdifulle merknader som løftet artikkelen til et høyere nivå, intervjuobjektene som tok seg tid til samtaler med forfatterne, samt deltakerne på en workshop ved Fridtjof Nansens institutt i januar 2018.

${ }^{2}$ Press release on Foreign Minister Sergey Lavrov's message to Norwegian Foreign Minister Ine Eriksen Soreide on the occasion of the 100th anniversary of the Svalbard Treaty. Russian Ministry of Foreign Affairs, 4 February 2020.
} 
private aktører, som i «Elektron»-saken - samt et ønske om diplomatisk løsning av eventuelle konfliktsituasjoner. Imidlertid har sentralmakten selv over tid - og særlig etter anneksjonen av Krim i 2014 - blitt mer nasjonalistisk og selvhevdende. Dette kan bety at Russland vil opptre tøffere overfor Norge i konfliktsituasjoner i fremtiden og eventuelt ønske å finne andre måter å hevde makt på i nordlige nærområder. Det samme kan skje dersom sentralmakten finner det nødvendig å respondere på andre aktørers (opinionens) misnøye med opplevd norsk «aggresion» og russisk «ettergivenhet». ${ }^{3}$ Endelig kan det tenkes at andre aktører - dersom misnøyen vokser seg stor nok uten at sentralmakten justerer sin kurs - velger å ta selvstendige initiativer på dette området.

I denne artikkelen søker vi å undersøke sannsynligheten for hvert av disse ulike hypotetiske scenarioene. Vi starter med å gjennomgå partenes posisjoner og bakgrunnen for disse posisjonene - først og fremst den russiske. Her trekker vi på Bercovitch, Kremenyuk og Zartman (2009), som argumenterer for at konflikt mellom stater stort sett kan tilskrives et begrenset sett faktorer. Deretter går vi i dybden på russiske persepsjoner og reaksjoner, både på føderalt og regionalt nivå, i perioden 1998 til 2018. Til slutt drøfter vi hvordan variasjonene i persepsjoner og reaksjoner over tid kan forklares, og hvilke implikasjoner som kan trekkes når det gjelder faren for fremtidige konflikter i området.

Artikkelen bygger i hovedsak på skriftlige kilder, med særlig vekt på russiske medieoppslag, ekspertkommentarer og intervjuer. Hovedtyngden av dette materialet ble innsamlet høsten 2018 gjennom søk på aktuelle russiske nettsider. I tillegg har vi hatt formelle intervjuer og uformelle samtaler med involverte aktører, først og fremst på norsk side, for å sikre oss flere perspektiver på de samme spørsmålene. Disse inkluderer den norske Kystvakten, Fiskeridirektoratet, Forsvarsdepartementet og Utenriksdepartementet. De formelle intervjuene ble gjennomført i november 2018 og januar 2019 og omfatter tre semistrukturerte intervjuer med representanter for Fiskeridirektoratet samt et e-post intervju med en representant for Kystvakten (fulgt opp muntlig i etterkant). Alle de intervjuede har vært, og er fortsatt, sentrale deltakere i fiskerisamarbeidet med Russland.

\section{Russland og Norge i vernesonen}

\section{Partenes syn på fiskevernsonen og dens status}

Den norsk-russiske konflikten rundt vernesonen springer ut av landenes ulike tolkning av Svalbardtraktaten av 1920. Traktaten gir Norge "full og uinnskrenket» suverenitet over øygruppen, men slår samtidig fast at borgere fra alle signatarstatene skal ha lik rett til å drive økonomisk virksomhet på øyene og i territorialfarvannet. ${ }^{4}$ Traktaten sier ingenting om havområdene utenfor territorialfarvannet - forståelig nok,

\footnotetext{
${ }^{3}$ Vi velger her å bruke anførselstegn for å påpeke at disse begrepene reflekterer ulike aktørers subjektive oppfatninger.

${ }^{4}$ Dvs. området ut til 12 nautiske mil (nm) fra grunnlinjene. Da Svalbardtraktaten ble inngått, gikk grensen for territorialfarvannet ved $4 \mathrm{~nm}$.
} 
siden prinsippet om 200-mils økonomiske soner først ble innført fra 1950-tallet og utover (Pedersen, 2009). Dette har skapt rom for ulike tolkninger av traktatteksten i vår tid, og signatarstatene har her inntatt ulike posisjoner (Pedersen, 2009). ${ }^{5}$

Norge tolker Svalbardtraktaten innskrenkende og anser at dens virkeområde også i dag begrenser seg til områdene som er uttrykkelig omtalt i teksten; selve øyene og deres territorialfarvann. Det norske synet er følgelig at Norge, som kyststat, kan opprette en fullverdig økonomisk sone rundt Svalbard. Dette synet bestrides imidlertid av flere andre traktatpartnere. For å kunne drive forsvarlig ressursvern, men samtidig unngå konfrontasjoner med andre stater, valgte Norge derfor i 1977 å opprette en midlertidig, ikke-diskriminerende fiskevernsone på 200 nautiske mil rundt Svalbard (Fløistad, 2008).

Blant de øvrige signatarstatene finnes det flere forskjellige syn. En del EU-aktører legger til grunn en dynamisk, eller utvidende, tolkning av Svalbardtraktaten. De anerkjenner Norges rett til å opprette en økonomisk sone - og dermed også landets rett til å utøve jurisdiksjon i sonen - men de hevder samtidig at sonen må være underlagt Svalbardtraktatens likebehandlingsbestemmelser (Østhagen \& Raspotnik, 2019). En del andre stater, i første rekke Russland, Spania og Island, har derimot bestridt Norges rett til å opprette noen slags maritime soner utenfor territorialfarvannet - og følgelig også Norges rett til å utøve jurisdiksjon i området. ${ }^{6}$ Som Pedersen (2009, s. 34) påpeker, er dette land som har betydelige fiskeriinteresser ved Svalbard.

Russiske myndigheter har med jevne mellomrom gjort det klart at de ikke anerkjenner vernesonen. Den gang sonen ble opprettet, reagerte Sovjetunionen med en protestnote, der det blant annet het at etableringen av sonen var i strid med Norges forpliktelser i henhold til Svalbardtraktaten (Fløistad, 2008). Den sovjetiske part påpekte spesielt at dette var et ensidig tiltak fra norsk side, noe enkelte har tolket som et uttrykk for misnøye med at Sovjetunionen ikke ble konsultert i saken (Fløistad, 2008). Når det gjelder områdets status, har Russland i en rekke diplomatiske noter gjort det klart at de anser havområdene utenfor Svalbards territorialfarvann som internasjonalt farvann. Pedersen (2009, s. 34) viser imidlertid til at denne posisjonen ikke er helt konsekvent:

Russland har ... gitt uttrykk for at Norge og Russland har et delt ... forvaltningsansvar utenfor Svalbard ..., men også tilkjennegitt at farvannene er internasjonale [og] at Svalbardtraktaten gjelder innenfor visse koordinater ... Med andre ord: Russlands posisjon er vag, inkonsekvent og omskiftelig, spesielt med tanke på hva slags regime russerne mener skal gjelde utenfor øygruppen, og har således først og fremst et taktisk preg.

\footnotetext{
${ }^{5}$ Dette gjelder de statene som har klargjort sitt syn på sonen. Et stort antall stater har sluttet seg til traktaten, men kun noen få har inntatt en eksplisitt posisjon i denne saken.

${ }^{6}$ Enkelte russiske eksperter, herunder Sennikov (2014), deler de nevnte EU-aktørenes synspunkt på den maritime sonen, men understreker at en tildeling av fiskeressurser ut fra historisk fiske ikke bryter med likebehandlingsbestemmelsene. Med andre ord anser de at Norge, dersom prinsippet om likebehandling skulle komme til anvendelse i sonen, ikke vil være forpliktet til å slippe til traktatpartnere som ikke tidligere har drevet fiske der.
} 
Russlands vingling på dette punktet skyldes nok blant annet at landet, som største fiskerinasjon ved Svalbard og medforvalter (sammen med Norge) av fiskebestandene i Barentshavet, tross alt har en sterk interesse av et forsvarlig ressursvern i området. Russiske myndigheter har derfor lagt seg på samme linje som sovjetmyndighetene $\mathrm{i}$ sin tid: Man godtar $i$ praksis at Norge gjennom Kystvakten driver kontroll i vernesonen, og russiske fiskere har instruks fra egne myndigheter om å legge til rette for inspeksjoner. Derimot skal fiskerne avstå fra fangstrapportering og underskriving av inspeksjonsskjema - som en symbolsk markering av at Russland $i$ prinsippet ikke anerkjenner norsk myndighet i sonen (Vylegzhanin \& Zilanov, 2007).

På russisk side vises det ofte til at denne praksisen er i samsvar med en gjensidig forstålse - gjerne omtalt som en "gentlemen's agreement» - som ifølge russiske kilder ble inngått mellom partene i sovjetperioden. Ifølge Vjatsjeslav Zilanov, tidligere sovjetisk vise fiskeriminister og representant i Den blandete norsk-sovjetiske fiskerikommisjonen, sikter begrepet til en muntlig overenskomst inngått mellom den norske havrettsminister Jens Evensen og den sovjetiske fiskeriminister Aleksandr Isjkov i forbindelse med et norsk-sovjetisk møte om vernesoneproblematikken i 1978 (Zilanov, 2016). Kjernen i denne forståelsen skal ha vært at Sovjetunionen aksepterte at Kystvakten inspiserte sovjetiske fartøy, mens Norge på sin side aksepterte at det var flaggstatens anliggende å ilegge eventuelle sanksjoner (Tsypalov, 2009; Portsel, 2012; Zilanov, 2016). Det faktum at Norge frem til sent på 1990-tallet praktiserte såkalt lempelig håndheving av regelverket i sonen, ved at man begrenset seg til å gi overtredere en advarsel, understøttet den russiske forestillingen om en slik "gentlemen's agreement». Dette er en viktig del av bakgrunnen for at russisk part reagerte så sterkt da Kystvakten i 2001 for første gang oppbrakte et russisk fartøy i vernesonen.

Enkelte russiske kommentatorer har tatt til orde for at man bør bringe spørsmålet om vernesonens status inn for en internasjonal domstol eller ta opp saken med de øvrige traktatpartnerne (Boldysjeva, 2011; Zilanov, 2018). Et mer utbredt syn er imidlertid at dette neppe vil være i Russlands interesse, da det vil kunne åpne opp for at tredjeland som ikke tidligere har drevet fiske i området, krever å få en andel av ressursene (Tsypalov, 2009; Fløistad, 2008).

\section{Russiske interesser i vernesonen}

Fiskeriene i vernesonen er, i motsetning til kulldriften på Svalbard, lønnsomme og dermed økonomisk viktige for Russland. Den russiske fiskeflåten tar en drøy fjerdedel av fangstene i Barentshavet nettopp i vernesonen, og Russland er største fiskerinasjon i sonen målt i årlig oppfisket kvantum. Denne andelen har vært økende i senere år, i forbindelse med at flere bestander har fått større utbredelse mot nord. I tillegg til fiskerienes betydning i dag er russiske fiskere og kommentatorer opptatt av historiske fiskerettigheter i sonen. Her vises det både til fangsthistorikk og til at russiske havforskere var tidligst ute med - og har gitt det største bidraget til utforsking og kartlegging av bestandene ved Svalbard (Zilanov, 2016; Vylegzhanin \& Zilanov, 2007). 
Vernesonens betydning for den russiske fiskeflåten må også ses i lys av at Russland tar en relativt liten andel av fangstene sine i russisk økonomisk sone (RøS). I RØS er fisken gjennomgående småfallen, og vær- og isforholdene er vanskelige (Zilanov, 2018). Tilgang til norske jurisdiksjonsområder - både norsk økonomisk sone (NØS) og vernesonen - er altså svært viktig for den russiske fiskeflåten. Russiske fiskere synes å oppleve at denne avhengigheten giør dem sårbare for press fra norske myndigheter:

[Vårt] land har aldri anerkjent Norges ... rett til å drive regulering og kontroll i havområdene ved Svalbard. Russiske redere kunne ... ha bestridt de norske domstolenes avgiørelser [om å bøtelegge russiske fartøyer] $\mathrm{i}$ internasjonale instanser, [men] om de i dag avstår fra å betale for overtredelser ved Svalbard og i morgen må gå for å fiske i norsk økonomisk sone, da kan det bli høyst ubehagelig for dem der [i NØS]. (Denisenko, 2009)

Rett nok medgir russiske eksperter og kommentatorer at det ville være en farlig strategi for Norge å stenge sine farvann for russisk fiske, siden et mer intensivt fiske på småfisken i øst vil kunne ha ødeleggende konsekvenser for bestandene. Frykten for at Russland kan bli «presset ut» av det vestlige Barentshavet synes likevel å være reell, og den er, som vi skal se, en av årsakene til motstanden i russiske fiskerikretser mot å anerkjenne Norges suverene rettigheter i vernesonen.

Russlands økonomiske interesser i området er også knyttet til fremtidige muligheter for petroleumsutvinning. Her har Russland inntatt en annen posisjon enn $\mathrm{i}$ spørsmålet om 200-milssonen. Det offisielle, russiske synet ser ut til å være at Svalbardtraktatens likebehandlingsprinsipper kommer til anvendelse på kontinentalsokkelen utenfor Svalbard. ${ }^{7}$ Igjen ser vi altså en inkonsekvens og et Russland som synes å agere mer taktisk enn prinsipielt.

Russlands militcere/sikkerhetsmessige interesser i området dreier seg først og fremst om å sikre Nordflåtens adgang til Atlanterhavet, sikre at Svalbard forblir demilitarisert og hindre at NATOs innflytelse i området øker (Rowe, 2018). Fra et russisk, militært synspunkt er det dermed ønskelig å begrense NATO-landet Norges suverenitet på Svalbard mest mulig og å hindre en "glidning» mot full anerkjennelse av Norges suverene rettigheter i vernesonen.

Selv om fiskeri- og forsvarsinteressene må antas å veie tyngst, er det mye som tilsier at en emosjonelt ladet forestilling om historisk urett stadig bidrar til å forme russiske oppfatninger av hva som er Russlands rettmessige rolle i området. Det er i Russland en utbredt oppfatning at landet på bakgrunn av historiske forhold har et minst like velbegrunnet krav på Svalbard som Norge. Russiske forskere, eksperter og

\footnotetext{
${ }^{7}$ De russiske protestnotene som ble overlevert i forbindelse med Norges utlysninger av leteblokker i området i 2013 og 2015, peker visstnok i denne retningen. Som svar på en henvendelse fra NRK opplyste den russiske ambassadens presseattaché således i en e-post at «[v]i har bedt Norge om å håndtere oljeaktivitet innenfor 'Svalbardkassen' i tråd med Norges forpliktelser under traktaten» (NRK, 2016).
} 
kommentatorer viser i denne sammenhengen til pomorenes tidlige bosetting og virksomhet på øygruppen, samt til historiske eksempler på at andre land har anerkjent Russland som en sentral aktør i området. ${ }^{8}$

Det faktum at Russland, på grunn av sin svekkede posisjon i 1920, ${ }^{9}$ var avskåret fra å delta i fremforhandlingen av Svalbardtraktaten, har vært med på å forme russiske persepsjoner av svalbardproblematikken i ettertid (Jørgensen, 2010; Vylegzhanin \& Zilanov, 2007), og narrativet om den svekkede stormakt ble reaktivert i den russiske svalbarddebatten etter Sovjetunionens fall.

Sovjetunionen valgte å slutte seg til Svalbardtraktaten i 1935, men sovjetiske myndigheter giorde jevnlige fremstøt for å få Norge til å innrømme landet en slags særstilling i området - såkalt bilateralisering (Jørgensen, 2010; Pedersen, 2016). Denne politikken fungerte til en viss grad - jamfør Norges tilbakeholdenhet med å «blande seg inn» i sovjetiske «interne forhold» på Svalbard (Jørgensen, 2010). Dette ser man også tendenser til i dag, særlig på fiskeriområdet, der russisk part har fremmet forslag om å opprette ulike fellesordninger (felles inspeksjoner, harmoniserte sanksjoner osv.) som man har ønsket å gjøre gjeldende både i vernesonen og $\mathrm{i}$ Barentshavet for øvrig. ${ }^{10}$ Det russiske presset for å få til fellesordninger har imidlertid bare fått Norge til å hegne desto sterkere om sine suverene rettigheter.

Oppsummert formes russiske persepsjoner på vernesoneproblematikken av flere faktorer som hver især kan være konfliktdrivende. Konflikt mellom stater kan, ifølge Bercovitch, Kremenyuk og Zartman (2009, s. 8), som i sin tur låner fra Mitchell (1981), stort sett tilskrives et begrenset sett faktorer: (a) ressurser, (b) suverenitet, (c) overlevelse, (d) ære og (e) ideologi. I den interne russiske debatten om vernesoneproblematikken finner vi at samtlige av disse faktorene er inne i bildet. Det handler om (a) fisk, (b) rettigheter i sonen, (c) sikkerhet og forsvar samt (d) opplevd historisk urett og (e) Russlands svekkede stormaktstatus. På norsk side vektlegges særlig suverenitetsaspektet, men det betyr ikke at det er det eneste som er viktig. Samlet sett peker dette mot et stort konfliktpotensial. Som Østhagen (2016, 2018) påpeker, er det imidlertid også en rekke stabiliserende faktorer inne i bildet, herunder det vellykkede fiskerisamarbeidet og det gode samarbeidet mellom de to statenes kystvakter. Vi kommer tilbake til disse spørsmålene mot slutten av artikkelen.

\footnotetext{
${ }^{8}$ Vylegzhanin \& Zilanov (2006) og Bekjasjev (2009) er blant dem som hevder at pomorene drev virksomhet på Svalbard lenge før Willem Barentsz oppdaget øygruppen i 1596. Se også Timtsjenko (1992) og Portsel (2011).

${ }^{9}$ Traktaten ble fremforhandlet av statene som gikk seirende ut av første verdenskrig, og Russland var ikke blant disse, ettersom landet hadde trukket seg ut av krigen og inngått separatfred med Tyskland tidlig i 1918. Dertil kom at ingen av statene som deltok i forhandlingene på dette tidspunktet, hadde anerkjent den russiske bolsjevik regjeringen, samt at Russland var midt inne i en blodig borgerkrig.

${ }^{10}$ Tankegangen er muligens at disse ordningene vil kunne forankres i det overordnede, bilaterale fiskerisamarbeidet i Barentshavet og dermed bli mer spiselige for både Norge og de øvrige traktatpartnerne.
} 


\section{Russiske persepsjoner og reaksjoner (1998-2018)}

Fra rundt år 2000 kan vi observere et skifte i norsk politikk der man forsøkte å etablere en sterkere presedens for regelverket i Barentshavet - og i vernesonen spesielt. Sett med norske øyne var det snakk om en slags normalisering: Norge gikk gradvis bort fra den tidligere praksisen med «lempelig håndheving» av regelverket for å kunne reagere adekvat på tilfeller av grov fiskerikriminalitet. ${ }^{11}$

Kosmo (2010) hevder at denne innstrammingen ikke var politisk styrt, men initiert av forvaltningen med bakgrunn $\mathrm{i} ø$ ønske om bedre kontroll på en torskebestand som på slutten av 1990-tallet ble beskrevet som dramatisk synkende (Østhagen, 2018, s. 108). Samtidig påpekes det at politikerne giennom lovgivning giorde dette mulig, samt at utviklingen nok var ønskelig siden den styrket sonens status (Kosmo, 2010; Hønneland \& Jørgensen, 2015; Skram, 2017). Uavhengig av hvorfor denne innstrammingen ble gjennomført, ble den av russiske aktører oppfattet som et avtalebrudd, og dette avfødte sterke reaksjoner - særlig i de første årene etter innstrammingen.

\section{Fase I, 1998-2005: Unison kritikk av Norges nye linje}

I 1998 anholdt Kystvakten for første gang en russisk tråler, "Novokuybysjevsk», i vernesonen. Flere fiskefelt i sonen var blitt stengt på grunn av stor innblanding av småfisk i fangstene (Skram, 2017), og da «Novokuybysjevsk» ble arrestert, befant tråleren seg i en gruppe på rundt 50 russiske fiskefartøy som alle fisket i stengt område (Kosmo, 2010, s. 32). Arrestasjonen førte til stor oppstandelse i Russland. Etter «hektisk diplomati» mellom partene endte det med en påtaleunnlatelse, og tråleren, som da var under eskorte til Tromsø, ble sluppet fri (Pedersen, 2009, s. 35). Hendelsen nørte likevel opp under en eksisterende misnøye med Norge i russiske fiskerikretser. Det norsk-russiske fiskerisamarbeidet var på den tiden preget av uenighet om flere viktige forvaltningsspørsmål, herunder størrelsen på de årlige torskekvotene (Hønneland \& Jørgensen, 2015).

I årene rundt årtusenskiftet kom det mye kritikk mot Norge, både fra fiskere, fra militært hold og fra regionale politikere. Fiskerne klaget over strengere reguleringer og strengere håndheving, og mange mente at Norges langsiktige mål var å fordrive hele den russiske fiskeflåten fra vernesonen. Representanter for det militære hevdet på sin side at Norges nye linje måtte ses i lys av at Norge var et redskap for NATO i nordområdene: Økt norsk innflytelse betydde økt NATO-innflytelse. Murmansk-guvernør Jurij Jevdokimov fridde til både fiskeri- og forsvarsinteressene gjennom å lansere en sponsorordning for russiske fiskerioppsynsfartøyer (slik at de skulle få råd til å gå ut på feltet og «beskytte» fiskerne) samt en adopsjonsordning for Nordflåtens ubåter (Jørgensen, 2010; Hønneland \& Jørgensen, 2015).

\footnotetext{
${ }^{11}$ «Lempelig håndheving» innebar i praksis at advarsel var den sterkeste reaksjonsformen som ble brukt. Kystvakten hadde imidlertid allerede fra 1993 brukt arrestasjoner og andre maktmidler i vernesonen mot tredjelandsfartøy som fisket uten kvote (Hønneland, 1999; Kosmo, 2010).
} 
Samtidig var det i enkelte miljøer en viss forståelse for at Norge strammet inn håndhevingen i sonen. Dette fremgår blant annet i en analyse fra Det russiske føderasjonsrådet (Tsypalov, 2009), der Norges linjeskift knyttes til økningen i russisk overfiske på 1990-tallet. Det understrekes spesielt at overtredelser ved Svalbard sjelden ble fulgt opp i det russiske rettssystemet, fordi svakheter i lovgivningen gjorde det vanskelig å straffeforfølge disse lovbruddene i Russland (Tsypalov, 2009, s. 77). Hovedproblemet var, ifølge analysen, at det russiske lovverket ikke åpnet for straffereaksjoner i forbindelse med overtredelser begått i internasjonalt farvann.

Det var imidlertid de kritiske reaksjonene som dominerte mediebildet. Et sentralt narrativ fra denne tiden er at Norge (nok en gang) utnyttet at Russland var midlertidig svekket. Følgende utdrag fra en artikkel publisert i 1999 er ganske tidstypisk:

I den senere tid har diskriminering av russiske interesser blitt et hverdagslig fenomen ... Norge driver en «stille» kampanje for å fordrive russiske fiskere fra sonen ved Svalbard ... I sovjetperioden var det ingen alvorlige hendelser. Norge ønsket ikke å krangle med sin sterke nabo i Øst. Etter oppløsningen av Sovjetunionen bestemte man i Oslo at det var tid for å handle. Nordmennene mente åpenbart at Russland ikke var i stand til å forsvare sine interesser fullt ut og begynte målrettet å fortrenge russiske fiskere fra sonen ... (Nezavisimoe voennoe obozrenie, 10. november 1999)

De føderale myndighetene var noe mer tilbakeholdne i sine reaksjoner så lenge de lyktes i å hindre at en ny håndhevingspraksis fikk gjennomslag - jamfør den avbrutte oppbringelsen av «Novokuybysjevsk». ${ }^{12}$ Men da «Tsjernigov» i 2001 ble oppbrakt og bøtelagt for grove overtredelser, kom det en meget kraftig offisiell reaksjon: Utenriksministeriet (MID) overleverte en note der man ikke bare beskyldte Norge for brudd på folkeretten, men også utelot de vanlige diplomatiske høflighetsfrasene (Pedersen, 2009, s. 25). I tillegg ble de russiske deltakerne på et møte i Det permanente utvalg under den blandete norsk-russiske fiskerikommisjonen hjemkalt i hui og hast - åpenbart etter ordre fra høyeste hold (Kosmo, 2010). Mye taler også for at deployeringen av ubåtjageren «Severomorsk» til vernesonen i 2002 var ment som et signal til Norge i forbindelse med arrestasjonen (Bruusgaard, 2006).

\section{Fase II, 2005-2012: Sentralmakten vs. opposisjonen}

Etter oppstyret rundt «Tsjernigov»-saken fulgte fire år uten arrestasjoner, og vernesoneproblematikken ble overskygget av andre saker. I 2005, derimot, spisset det hele seg til med den mislykkede oppbringelsen av «Elektron». Mediedramaet og dekningen av saken var med på å sette den høyt på den politiske agendaen i Norge (Fermann \& Inderberg, 2015). Hendelsen fikk også enorm oppmerksomhet i Russland, først og fremst på grunn av det spektakulære forløpet. Til tross for dette var reaksjonene på russisk side mer blandet enn i «Tsjernigov»-saken.

\footnotetext{
${ }^{12}$ En lignende hendelse i år 2000 med et ikke-navngitt fartøy fikk samme utfall (Osen, 2004).
} 
Det mest påfallende var at de offisielle reaksjonene var langt mer dempet i 2005 enn i 2001. MID var nøkterne i sine kommentarer til pressen og gikk raskt i dialog med norske myndigheter. Allerede før «Elektron» klappet til kai i Murmansk, erklærte utenriksminister Sergej Lavrov at Norge og Russland burde gjennomføre drøftinger om «statusen til havområdene ved Svalbard». Dette skjedde visstnok på direkte oppfordring fra president Putin (Bekjasjev, 2006, referert i Shut, 2012, s. 63). Lederen for Grensetjenesten i Murmansk benektet at arrestasjonen var i strid med internasjonal rett, mens den russiske lederen for Fiskerikommisjonen uttalte at «nordmennene, forståelig nok, var nødt til å reagere på det ukontrollerte fisket som går hånd i hånd med [Russlands] passivitet» (NTV, 2005; sitert i Shut, 2012, s. 64).

På regionalt nivå i Murmansk kom det derimot krasse uttalelser mot Norge, både fra redere og lokale parlamentarikere. Sinnet rettet seg også mot egne myndigheter. For eksempel fikk sjefene for forsvaret og den føderale sikkerhetstjenesten (FSB) kritikk for manglende vilje til å beskytte egne borgere (Aftenposten, 22. oktober 2005). I media ble skipperen på "Elektron» dels hyllet som en helt, dels fremstilt som en tjuvfisker som satte Russland i forlegenhet.

Fra og med «Elektron»-saken ser vi altså et skille mellom en dialogorientert sentralmakt og en konfliktorientert "opposisjon» når det gjelder vernesoneproblematikken. Lavrovs ønske om bilaterale drøftinger ble fulgt opp i Fiskerikommisjonen, der fiskeriene ved Svalbard ble et fast punkt på dagsordenen fra og med 2005. I årene som fulgte (2006-2010), ble seks trålere arrestert i vernesonen uten at det kom formelle protester fra Russland (Østhagen, 2018, s. 107-111).

Samtidig tok myndighetene visse skritt for å «beskytte» russiske fiskere i sonen. I 2008, da den stridbare Andrej Krainij hadde overtatt som leder for Det føderale fiskeribyrået, sendte fiskerimyndighetene for første gang på mange år oppsynsskip til vernesonen. I en artikkel i tidsskriftet Ekspert Severo-Zapad fremgår det at de leide inn fire fartøy for å drive kontroll i «det omstridte området» samt for å forebygge «overdrevent press» mot russiske fartøy fra Kystvaktens side (Denisenko, 2009). Ifølge artikkelen minsket dette presset merkbart når russiske oppsynsskip var til stede. I minst ett tilfelle tok inspektører fra oppsynsskipet "Angrapa» seg om bord i et fiskefartøy og blandet seg direkte inn i en av Kystvaktens inspeksjoner (Denisenko, 2009). ${ }^{13}$

I praksis hadde den russiske fiskerietatens sivile oppsynsfartøyer lite å stille opp med mot den norske Kystvakten. Dette ble fremholdt som et problem, blant annet i den ovennevnte artikkelen. Imidlertid var Den russiske grensetjenesten, som sorterer under FSB, på dette tidspunktet i gang med å bygge opp en moderne, russisk

\footnotetext{
${ }^{13}$ Av protokollen fra sesjonen i Fiskerikommisjonen i 2009 fremgår det at norske myndigheter satte lite pris på denne innblandingen: «Den norske part minnet om at det tilligger Norge som kyststat både rett og plikt til å sikre at de levende, marine ressurser i havområdet ved Svalbard ikke overbeskattes. Som kyststat har Norge alene rett til å treffe reguleringstiltak og til å håndheve disse ... Den norske part forventer at russisk fiskerioppsyn ... ikke hindrer den norske Kystvakten $i$ utøvelsen av dens mandat) (Protokoll for den 38. sesjon i Den blandete norsk-russiske fiskerikommisjon, 2009, s. 14, vår utheving).
} 
kystvakt (Åtland, 2016). På et møte i Regjeringskommisjonen for Svalbard i 2011 drøftet man også mulighetene for å bruke Nordflåten samt strategiske, langtrekkende bombefly på tokt i Nordishavet for å verne om russiske interesser i Svalbard-området. Det man diskuterte, var imidlertid styrkedemonstrasjoner og ikke direkte inngripen fra militære fartøy og fly (Portsel, 2012, s. 14-15).

I Fiskerikommisjonen var den russiske parten på den ene siden opptatt av å markere sin rett til å drive inspeksjoner i vernesonen, på den andre siden av å få til harmonisering av norske og russiske fiskeriregler. ${ }^{14}$ I 2009-2010 ble partene enige om felles regler for maskevidde i trål, minstemål på fisk og stenging/åpning av fiskefelt. Russiske fiskere hadde lenge klaget over at de måtte følge norske regler når de fisket i vernesonen, så dette var et viktig bidrag for å forebygge konflikter.

\section{Mellomspill 20I0-20II: uroen rundt delelinjeavtalen og «Sapfir-2»-saken}

Den interne konflikten mellom den russiske sentralmakten og den norges kritiske «opposisjonen» nådde et høydepunkt etter at delelinjeavtalen ble inngått i 2010. Etter avtaleinngåelsen drev en allianse bestående av fiskere, regionalpolitikere og eksperter intens lobbyvirksomhet for å hindre at Russland ratifiserte avtalen. De hevdet at avtalen innebar en implisitt anerkjennelse av norske suverene rettigheter i vernesonen, og kom med advarsler om at presset mot russiske fiskere ville øke (Hønneland, 2013). Noen spådde at antall arrestasjoner av russiske fartøy kom til å eskalere i etterkant av ratifiseringen. Myndighetene i Moskva gjorde samtidig alt de kunne for å hindre opposisjonen $\mathrm{i}$ å ødelegge for ratifiseringen av avtalen. Her spilte både mediekontroll og press mot politikere en rolle (Moe et al., 2011; Ims, 2013; Hønneland, 2016).

I 2011 - året da avtalen ble ratifisert - ble i alt fem russiske trålere arrestert av Kystvakten i vernesonen, og fiskerne og deres støttespillere tok (forståelig nok) dette som en bekreftelse på at de hadde hatt rett. Redere og lokalpolitikere i Murmansk beskrev arrestasjonene som «aggressive handlinger» med formål å «jage» russiske fiskere ut av Barentshavet (Nevskoe vremja, 27. oktober 2011). De kom også med harde utfall mot egne myndigheter. En representant for parlamentet i Murmansk beskyldte for eksempel MID for å stille seg på (de norske) «inntrengernes» side (Nevskoe vremja, 27. oktober 2011).

Det hele kulminerte høsten 2011, da tråleren «Sapfir-2» ble oppbrakt for utkast av fisk. En rekke oppslag i russiske medier beskriver arrestasjonen som uvanlig dramatisk. Også i denne saken skal skipper ha tilkalt "Angrapa», og medieoppslagene gir inntrykk av Kystvaktens inspektører opptrådte nærmest brutalt for å hindre at russiske inspektører kom tråleren til unnsetning. Det hadde ikke kommet noen offisielle protester mot arrestasjonene før «Sapfir-2», men nå overleverte MID en særdeles skarp note til Norges ambassadør. Der het det blant annet at Norges handlinger

\footnotetext{
${ }^{14}$ Dette fremgår av de årlige protokollene fra sesjonene for fiskerisamarbeidet. Protokollene er publisert på www.jointfish.com/.
} 
hadde en "uakseptabel og utfordrende karakter». Det ble også spesielt påpekt at det hadde vært mange arrestasjoner i vernesonen den siste tiden (Portsel, 2012, s. 52).

På møtet i Fiskerikommisjonen noen uker etter arrestasjonen var det en anspent stemning..$^{15}$ Etter russisk ønske ble det i februar 2012 avholdt en ekstraordinær sesjon om fisket ved Svalbard. Her ble man enige om «snarest mulig» å utarbeide en omforent definision av begrepet "utkast». I tillegg skulle en arbeidsgruppe jobbe med felles retningslinjer for inspeksjoner (Den blandete norsk-russiske fiskerikommisjon, 2012).

Dette sier en god del om hva de russiske fiskerne på dette tidspunktet oppfattet som de største problemene knyttet til fisket i vernesonen. I 2012 hadde de fleste arrestasjonene nettopp dreid seg om utkast av fisk. Enkelte hevdet derfor at den norske Kystvakten, etter at øvrig regelverk var blitt harmonisert, nå var gått over til å bruke utkast som påskudd for å kunne fortsette å arrestere russiske fartøy. Dette resonnementet dukket opp i media allerede før den siste runden med harmoniseringer var i havn (Denisenko, 2009). Mange klaget også over at Kystvaktens inspeksjoner tok for lang tid.

\section{Fase III, 20I2-20I8: Kontroll og dempede reaksjoner}

Siden 2012 har det vært langt mindre uro om vernesonen internt i Russland enn det var rundt årtusenskiftet og i perioden rundt inngåelsen og ratifiseringen av delelinjeavtalen i 2010-2011. Arrestasjonene som har funnet sted i sonen etter 2011, har fått svært beskjeden mediedekning, og i artikler og kommentarer som dreier seg om vernesoneproblematikken, brukes nå oftest gamle saker ("Elektron", "Sapfir-2») som illustrasjon. Derimot fikk arrestasjonen av den norske tråleren «Remøy» $\mathrm{i} \emptyset \mathrm{R}$ våren 2017, samt ileggelse av en sviende bot for et forhold tråleren ikke kunne lastes for, relativt fyldig omtale i nordvestrussiske medier. På norsk side ble det spekulert i om arrestasjonen kunne være en slags «hevn» for tidligere tiders ydmykende arrestasjoner av russiske fartøy (Fiskeribladet, 26. mai 2017).

En viktig grunn til at debatten rundt vernesoneproblematikken har stilnet, er nok at relativt få russiske fartøy har blitt arrestert i sonen i senere år (se tabell I). Enda viktigere er det kanskje at de fleste av disse sakene - og alle saker etter 2013 har blitt «løst i sjøen». Dette er en prosedyre som første gang ble brukt i 2012, og som innebærer at fartøyene ikke oppbringes til norsk havn, men slippes fri når det er stilt garanti som sikrer at eventuell bot og inndragning vil bli betalt. ${ }^{16}$ Før denne ordningen ble innført, kom det jevnlige klager fra russiske fiskebåtredere over at kun

\footnotetext{
${ }^{15}$ Intervju, Fiskeridirektoratet, 20. november 2018.

${ }^{16}$ «Sakte oppbringelse» (som prosedyren formelt kalles) er basert på et samarbeid mellom Kystvakten og statsadvokatembetene i Troms, Finnmark og Rogaland. Det er utarbeidet egne retningslinjer for "sakte oppbringelse» i fiskerisaker. Blant annet er det et krav at det ikke "foreligger relevante behov for etterforskning eller bevissikring utover det Kystvakten kan gjennomføre i sjøen». Prosedyren brukes i alle norske jurisdiksjonsområder (personlig kommunikasjon med Kystvakten, 8. januar 2019; Troms og Finnmark statsadvokatembeter og Rogaland statsadvokatembeter 2014).
} 
utenlandske fiskefartøy ble oppbrakt i forbindelse med arrestasjoner i norske jurisdiksjonsområder. Rederne oppfattet dette som diskriminerende, blant annet fordi det innebar store kostnader i form av tapt fisketid. Kystvaktens klare inntrykk er at den nye ordningen har virket konfliktdempende, ${ }^{17}$ og dette underbygges av den relative tausheten om temaet i russiske media.

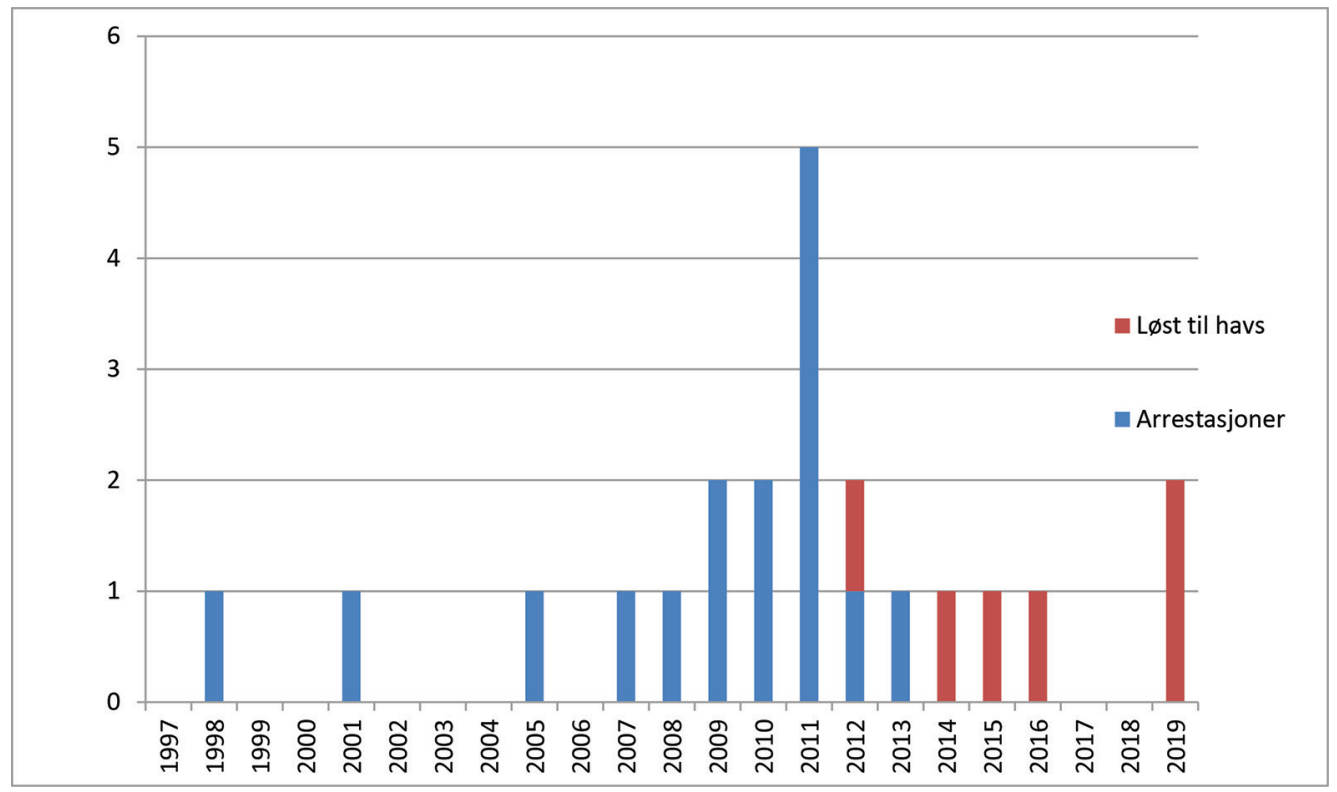

Figur 1 Oversikt over Kystvaktens arrestasjoner i vernesonen mellom 1997 og 2019. Data fra Kystvakten og fra Arild-Inge Skrams bok Alltid til Stede (2017, s. 151).

Tidvis kommer det likevel «drypp» som viser en fortsatt kritisk holdning til Norge. Fiskerinestor Zilanov hevdet for eksempel i et intervju i 2016 at inspeksjoner av russiske fartøy har «en ydmykende karakter» (Potasjov, 2016). Han ga også uttrykk for at reglene for utkast tolkes for strengt: «[H]vis en sildespord faller over bord eller trålen tilfeldigvis revner idet den tas opp, da kan ikke det anses som en overtredelse ...» (Potasjov, 2016).

I en e-postutveksling med forfatterne i 2018 utdypet Zilanov sitt syn på utkastproblematikken:

Utkast er norsk "oppfinnelse», og nordmennene viser en konsekvent mangel på interesse for å gi begrepet en praktisk fortolkning. Hvorfor? [Fordi] dette er en fordelaktig situasjon for den norske kystvakten, slik at de kan fortsette å arrestere fiskere, særlig russiske. Nordmennene er ikke interessert i å løse dette problemet. $^{18}$

\footnotetext{
${ }^{17}$ Personlig kommunikasjon med Kystvakten, 8. januar 2019.

${ }^{18}$ Personlig kommunikasjon med Vjatsjeslav Zilanov, 16. november 2018.
} 
Samme type kritikk har tidvis kommet også fra annet hold, særlig med hensyn til utkast, men i noen grad også når det gjelder Kystvaktens inspeksjonspraksis (se f.eks. Sennikov, 2014). Omfanget er imidlertid et helt annet enn i tidligere perioder. I dag synes det å være snakk om en mindre gruppe kritiske røster som bruker det som er igjen av ankepunkter for alt de er verdt.

Prosessene som ble initiert på Fiskerikommisjonens sesjon i 2011 (omforent definisjon av begrepet «utkast», felles retningslinjer for inspeksjoner), var nettopp innrettet mot å håndtere disse ankepunktene. I årene som fulgte forsøkte partene $\mathrm{i}$ kommisjonen å komme frem til løsninger som begge kunne godta, men dette viste seg å være vanskelig. Den russiske parten ville ha konkrete og strenge begrensninger med hensyn til varigheten av inspeksjonene, antall inspektører som normalt kunne delta, med mer. Videre ønsket de felles retningslinjer, ikke bare for selve inspeksjonsfasen, men også for etterforskningsfasen, som i Norge ligger inn under påtalemyndigheten. ${ }^{19}$ Dette kunne ikke den norske parten akseptere, og arbeidet ble «midlertidig» stanset i 2015.

Spørsmålet om utkast var også særdeles krevende. Hovedproblemet var at den russiske parten ønsket en presis og avgrenset utkastdefinisjon, mens den norske parten mente at håndhevingen ville bli vanskelig om det ikke var rom for bruk av skjønn. Så langt har partene ikke klart å bli enige om en ny, omforent definisjon. Man har isteden prioritert å få ut informasjon til fiskerne om partenes ulike regler på dette området. Det føderale fiskeribyråets territoriale avdeling for Barentshavet og Kvitsjøen (BBTU) legger for eksempel jevnlig ut informasjon til fiskerne om norske reguleringer i både NØS og vernesonen. ${ }^{20}$

Alt i alt har stemningen i Fiskerikommisjonen og dens underorganer blitt bedre i senere år. Stemningsskiftet i kommisjonen synes dels å ha med personsammensetningen å gjøre. Blant annet gikk Andrej Krajnij, som sto for en temmelig norges kritisk linje, i 2014 av som leder for Fiskeribyrået - og dermed også som russisk leder i kommisjonen (intervjuer i Fiskeridirektoratet, 20. november 2018). Norske deltakere i samarbeidet opplever at det arbeides konstruktivt for å identifisere saker man kan bli enige om, og at man for øvrig er «enige om å være uenige». Deltakerne i samarbeidet opplever ikke at forverringen av det norsk-russiske forholdet på politisk nivå etter 2014 har innvirket direkte på kommisjonens arbeid. ${ }^{21}$

\footnotetext{
${ }^{19}$ Personlig kommunikasjon med Kystvakten, 8. januar 2019; Intervjuer i Fiskeridirektoratet, 20. november 2018.

${ }^{20}$ Etter at en russisk tråler i 2016 ble arrestert for utkast i vernesonen, påpekte BBTU at «det er nødvendig å overholde fiskerireglene ... og andre tiltak fastsatt i russisk lov og internasjonale avtaler» (BBTU, 2016). Presiseringen «russisk lov ...» innebar at meldingen ikke sto i motstrid til russisk offisiell politikk. Samtidig fungerte den som en påminnelse om at brudd på det norske regelverket i vernesonen innebærer en fare for å bli arrestert.

${ }^{21}$ Personlig kommunikasjon med Kystvakten, 8. januar 2019; Intervjuer i Fiskeridirektoratet, 20. november 2018.
} 
Parallelt med at ting har roet seg ned i Fiskerikommisjonen, har det russiske nærværet i vernesonen blitt mer merkbart. Det er ikke lenger fiskerimyndighetene, men den russiske kystvakten som har ansvar for patruljeringen i området. Siden den formelle etableringen i 2007 har kystvakten vært gjennom en omfattende modernisering, og det kan se ut til at etatens oppgaver etter hvert har rykket høyere opp på den russiske regjeringens prioriteringsliste (Åtland, 2016). De aller siste årene har etaten fătt tilført flere nye, moderne fartøy. I 2017 alene fikk russisk kystvakt tre nye skip, og ytterligere to var under bygging (Etterretningstjenesten, 2018). Flere av disse er isforsterket, og minst ett er utstyrt med helikopter (TV21, 30. januar 2009). Den norske Kystvakten står derimot uten helikoptre i skrivende stund på grunn av problemer hos den italienske leverandøren. ${ }^{22}$

På tross av Russlands svekkede økonomi har det de siste årene vært en moderat økning i den russiske kystvaktens patruljevirksomhet i vernesonen. Derimot har russisk kystvakt flere ganger uteblitt fra møter i Fiskerikommisjonens underorganer og andre internasjonale fora, og de norske samarbeidspartnerne har inntrykk av at dette har økonomiske årsaker. Det ser altså ut til at patruljevirksomheten prioriteres høyt (intervjuer i Fiskeridirektoratet, 20. november 2018; personlig kommunikasjon med Kystvakten, 8. januar 2019). Moderniseringen av flåten har muliggjort patruljering i større deler av året enn tidligere, og det helikopterbærende fartøyet «Poljarnaja Zvezda» opptrer jevnlig i området. ${ }^{23}$ Imidlertid har det ikke vært noen forsøk på innblanding i norske inspeksjoner i vernesonen siden «Sapfir-2»-episoden - der det altså var snakk om et fartøy fra den regionale fiskerioppsynsetaten og ikke et kystvaktfartøy.

Samtidig tyder flere uttalelser fra representanter for russisk kystvakt på at man har en ambisjon om å oppnå en form for paritet med den norske Kystvakten i vernesonen. I 2016 hevdet for eksempel sjefen for Grensetjenesten i et intervju at etatens fartøy driver oppsyn ved Svalbard "sammen med» den norske Kystvakten, og at de inspiserer «både russiske og utenlandske fiskefartøy» (FSB, 2016). ${ }^{24}$ Grensetjenestens pressesjef i Murmansk ga likeledes i et intervju i 2012 inntrykk av at man hadde en avtale om at den norske Kystvakten "som regel» skulle avstå fra å kontrollere russiske fartøy når russiske kystvaktfartøy var i området (B-port, 26. oktober 2012).

Her dreier det seg nok enten om svært dårlig informasjonsflyt oppover $\mathrm{i}$ systemet, eller, mer sannsynlig, om «alternative fakta» beregnet på hjemmepublikummet. Norsk kystvakt opplyser at man ikke har noen form for samarbeid med den russiske part i vernesonen ut over utveksling av høflighetsfraser på radio, og at felles inspeksjoner i sonen er fullstendig uaktuelt - selv om den russiske part ved flere

\footnotetext{
${ }^{22}$ Denne situasjonen har vedvart i flere år, og p.t. er det forventet at helikoptrene vil bli levert til Kystvakten først i 2022 (VG, 18. september 2018).

${ }^{23}$ Personlig kommunikasjon med Kystvakten, 8. januar 2019.

${ }^{24}$ Takk til Arild Moe, som gjorde oss oppmerksomme på dette oppslaget.
} 
anledninger har ytret ønske om dette. ${ }^{25}$ Man har heller aldri observert at russiske kystvaktfartøy har prøvd å inspisere tredjelandsfartøy i sonen. ${ }^{26}$

Oppsummert har altså uroen lagt seg, både i russiske fiskerikretser og i Fiskerikommisjonen, mens det russiske nærværet i vernesonen er trappet opp. Samtidig har en rekke russiske ekspertkommentatorer gitt uttrykk for at det norske synet på sonens status har blitt styrket som følge av delelinjeavtalen (Kalasjnikov, 2011; Zilanov, 2018). Resonnementet som går igjen, er at Russland, gjennom sin tilslutning til en grenselinje også i de nordlige delene av Barentshavet, implisitt har anerkjent at «det som befinner seg på den andre siden» - altså vernesonen - er norsk jurisdiksjonsområde. Også enkelte norske eksperter deler dette synet. ${ }^{27}$

Det har også kommet flere tegn på at den mer overordnete konflikten rundt Svalbard samt øygruppens strategiske posisjon ikke er glemt i Russland. Høsten 2017 brakte en rekke russiske aviser utdrag fra en «lekket» rapport fra det russiske Forsvarsministeriet. Avisen Kommersant refererte deler av innholdet som følger:

Som en spesiell trussel nevnes Norge og dets planer om unilateral revisjon av internasjonale avtaler. I rapporten understrekes det at landets myndigheter streber mot å opprette «absolutt nasjonal jurisdiksjon over øygruppen Svalbard og den tilliggende 200-milssonen». (Kommersant, 3. oktober 2017)

Ifølge MID har russiske myndigheter dessuten flere ganger bedt om samtaler med Norge om uenighetene vedrørende Svalbard - men uten å komme noen vei (Grønning, 2017). På et møte i Barentsrådet, som fant sted kort etter at den ovennevnte rapporten ble omtalt i russiske medier, beklaget utenriksminister Lavrov seg over situasjonen til sin norske kollega Børge Brende:

Det russiske utenriksministeriet overleverte i fjor to diplomatiske noter om Svalbard til den norske part, men uten at det har kommet noen respons. Vi har i flere tilfeller bedt om dialog om disse spørsmålene, men nordmennene svarer ikke. Jeg synes ikke dette rimer med et godt naboforhold. (Barents Observer, 19. oktober 2017)

Av det mer kuriøse slaget er utspillet som Vjatsjeslav Sjtyrov, leder for Føderasjonsrådets Arktis- og Antarktisråd, kom med under en spørretime i Føderasjonsrådet i

\footnotetext{
${ }^{25}$ Personlig kommunikasjon med Kystvakten, 8. januar 2019. Et konkret eksempel er omtalt i Kyst og Fjord (2012). Det refereres til et brev fra den daværende lederen for FSB, Sergej Kudrjasjov, til det norske Forsvardepartementet, der Kudrjasjov ytret ønske om «et mer formelt samarbeid, med felles norsk-russiske fiskeriinspeksjoner i det fiskerike området rundt Svalbard".

${ }^{26}$ Personlig kommunikasjon med Kystvakten, 16. januar 2019. Det er for øvrig vanskelig å forestille seg at noe slikt skulle ha passert ubemerket, da det formodentlig ville ha ført til skarpe protester fra vedkommende tredjeland.

${ }^{27}$ Forsker og statsviter Torbjørn Pedersen, som i 2008 leverte sin doktoravhandling om svalbardproblematikken, kom med følgende kommentar til avtaleinngåelsen i 2010. «Dette [en grenselinje som går helt opp til Polhavet] hadde ikke vært mulig dersom Russland fortsatt anså havområdene utenfor Svalbard som internasjonalt farvann. En ratifisering av avtalen vil indikere at Russland erkjenner at Norge har en viss myndighet over havområdene utenfor Svalbard, noe som harmonerer bedre med folkeretten» (Forskningsrådet, 4. november 2010).
} 
desember 2017. Sjtyrov tok til orde for at Russland skulle sammenkalle Svalbardtraktatens signatarmakter til en ny konferanse med sikte på å få traktaten omstøtt. «I så fall», mente han, «vil vårt land ha fortrinnsrett» (Ura News, 18. desember 2017).

\section{Slutninger og implikasjoner}

\section{Russiske persepsjoner og reaksjoner over tid: mulige forklaringsfaktorer}

Etter oppløsningen av Sovjetunionen var det mange i Russland som mente at Norge/ Vesten gikk målrettet inn for å utnytte Russlands svekkede posisjon til egen fordel. Innstrammingen i norsk håndhevingspraksis i vernesonen på slutten av 1990-tallet kunne lett tolkes i den retning. Mens mange på norsk side betraktet dette som en normalisering, muliggjort av avspenningen mellom øst og vest, ble det på russisk side oppfattet som et avvik fra normalen - og dertil som et regelrett avtalebrudd muliggjort av Russlands midlertidige svakhet. Det er derfor ikke overraskende at Russland reagerte mot denne innstrammingen.

Siden har det imidlertid vært store variasjoner i den russiske responsen på norsk håndhevingspraksis i vernesonen, både over tid og mellom grupper av aktører. Som det fremgår av vårt materiale, har de sterkeste reaksjonene kommet fra regionale aktører, først og fremst fiskebåtrederne og deres støttespillere i Nordvest-Russland. Kritikken fra disse aktørene var særlig høylytt rundt årtusenskiftet og i tiden rundt inngåelsen av delelinjeavtalen, mens den stilnet av etter 2011.

Russiske føderale myndigheter har, naturlig nok, ordlagt seg mer diplomatisk enn fiskerne, men også de var innledningsvis meget kritiske til Norges nye linje - jamfør avviket fra diplomatisk kutyme i noten som ble oversendt etter arrestasjonen av «Tsjernigov». Fra og med "Elektron»-saken ser vi imidlertid at sentralmakten satset på en dialogorientert tilnærming, med unntak av en kort periode etter arrestasjonen av «Sapfir-2».

Vi finner altså to vendepunkter: Ett i 2005, da sentralmakten gikk over fra protest til dialog, og ett etter 2011, da kritikken fra fiskerne og deres støttespillere stilnet. Derimot finner vi ikke at 2014 fremstår som noe vendepunkt, tross forverringen i det bilaterale forholdet etter annekteringen av Krim. Hvordan kan denne dynamikken forklares?

Som vi var inne på i innledningen, har konflikten rundt vernesonen flere sider enn de rent juridiske. Russland har omfattende interesser i området, både av militær og økonomisk karakter, og i tillegg finnes det en historisk dimensjon som det er knyttet sterke følelser til.

Fiskebåtrederne har i sin kritikk av Norge og Kystvakten vist til alle disse forholdene, men det betyr ikke at alle veier like tungt. Selv om de har pakket protestene sine dels i nasjonalistiske, dels i juridiske termer, virker det som om russiske fiskere i bunn og grunn er mest opptatt av praktiske problemer med utøvelsen av fisket. Det de først og fremst har fryktet, er forverrede rammevilkår for det russiske fisket i vernesonen $-\mathrm{i}$ verste fall at russiske fiskere blir presset ut. 
Kampanjen i forkant av delelinjeavtalen, der ideologisk motiverte kommunister og nasjonalister malte fanden på veggen, bidro til å skjerpe fiskernes frykt for at den norske parten hadde underliggende motiver. Denne frykten ble selvsagt ytterligere forsterket da Kystvakten arresterte et rekordhøyt antall russiske fiskefartøy i vernesonen nærmest før blekket var tørt på ratifikasjonsdokumentet.

At protestbølgen fra "fiskeropposisjonen» i 2010-11 likevel ble et forbigående fenomen, skyldes delvis at regionenes svekkede stilling gjorde det kostbart for regionale politikere å fortsette å utfordre sentralmaktens politikk. Det viktigste var likevel at nedgangen $i$ antall arrestasjoner fra og med 2012, og ikke minst den nye ordningen med løsning av saken i sjøen, virket sterkt beroligende på russiske fiskere. Harmoniseringen av norsk og russisk fiskeriregelverk i Barentshavet samt Fiskerikommisjonens arbeid for å få ut informasjon om partenes nasjonale reguleringer gjorde det dessuten enklere for russiske fiskere å operere både i vernesonen og i NØS. Siden den regionale motstanden mot norsk politikk i vernesonen i så stor grad var basert på fiskernes misnøye, ble det vanskelig å videreføre den.

Når det gjelder de føderale myndighetenes reaksjonsmønster, er bildet mer komplekst. Ulike etater har ulike prioriteringer og til tider også noe ulike verdensbilder og ideologiske ståsteder. I tillegg pågår det hele tiden en maktkamp mellom ulike strukturer.

På slutten av 1990-tallet var makten i Russland svært fragmentert. Sektorinteresser og private interesser gjorde seg gjeldende på mange politiske områder - ikke minst på fiskerifeltet. I den bilaterale Fiskerikommisjonen bidro et stort innslag av norges kritiske redere til et høyt konfliktnivå. Da Kystvakten begynte å skjerpe håndhevingen, var de russiske reaksjonene sterke, men ukoordinerte. Ulike grupperinger fikk utløp for sin vrede, men dette fikk ikke annet enn forbigående effekter på den norske politikken.

Etter hvert som Vladimir Putin festet grepet om makten utover på 2000-tallet, fremsto Russland i større grad enn før som en enhetlig aktør - i hvert fall i utenrikspolitikken. Da russiske myndigheter fikk «Elektron»-saken i fanget i 2005, hadde Putin konsolidert sin stilling, og styrkingen av «maktvertikalen» hadde pågått i flere år. Gitt den store oppmerksomheten rundt saken er det liten grunn til å tvile på at presidenten var direkte involvert $\mathrm{i}$ beslutningen om hvordan den skulle håndteres og, som vi har sett, valgte sentralmakten dialog fremfor konfrontasjon.

Akkurat det er ikke spesielt overraskende. I sine tidlige presidentperioder satset Putin på en pragmatisk politikk på de fleste områder. Rett nok hadde han som mål å gjenreise Russland som stormakt, men han mente at dette best kunne oppnås gjennom stabilisering og økonomisk vekst. Han var dessuten opptatt av at Russland skulle fremstå som en pålitelig og ansvarlig samarbeidspartner i forholdet til andre land - ikke minst i Arktis. Flere analyser har pekt på at sentraliseringen under Putin bidro til at det norsk-russiske fiskerisamarbeidet utviklet seg i positiv retning $\mathrm{i}$ årene etter årtusenskiftet. Dette kommer blant annet frem hos Bruusgaard (2006), Shut (2012) og Hønneland og Jørgensen (2015). 
Som Jørgensen (2010) har påpekt, kunne fraværet av offisielle protester mot arrestasjoner av russiske fartøy i vernesonen tolkes som en stilltiende aksept av Norges rett til å utøve jurisdiksjon i vernesonen. Russiske myndigheter sendte imidlertid flere signaler om at man ikke var innstilt på noen form for ettergivenhet. Snarere syntes den russiske parten å følge samme linje som Sovjetunionen i sin tid; å legge mildt press på Norge for å prøve å oppnå en særstilling for Russland i området herunder gjennom å fremme forslag om ulike fellesordninger og gjennom å sende russiske oppsynsskip til vernesonen. Formodentlig kom initiativet til det siste fra Fiskeribyrået/Krajnij, men man må anta at den øverste politiske ledelsen var innforstått med dette. Oppbyggingen av en moderne russisk kystvakt i nord er også en del av dette bildet.

Parallelt med Svalbard-drøftingene i Fiskerikommisjonen kom det fart i forhandlingene om en delelinje i Barentshavet. Russlands fornyede interesse for delelinjen har blant annet blitt knyttet til et ønske om stabile rammebetingelser rundt fremtidig petroleumsutvinning i Barentshavet. Enkelte har også pekt på prosessen rundt Russlands kontinentalsokkelkrav, med henvisning til at avklarte soneforhold i området ville øke sjansene for en anbefaling fra FNs sokkelkommisjon i pakt med det russiske kravet (Moe, Fjærtoft \& Øverland, 2011). Hensynet til forhandlingene kan ha bidratt til at russiske myndigheter ønsket å unngå å tilspisse konflikten om vernesonen. Samtidig må russiske myndigheter ha vært klar over at en avtale kunne bli tolket som en støtte til Norges posisjon i denne saken. Flere russiske havrettsjurister argumenterte mot delelinjen nettopp på dette grunnlaget. Her må Putin og den øvrige politiske ledelsen simpelthen ha gjort en pragmatisk avveining mellom ulike interesser.

Da ratifiseringen av avtalen ble fulgt av et uvanlig høyt antall arrestasjoner av russiske fartøy i vernesonen, kom sentralmaktens dialogorienterte linje under sterkt press. I denne situasjonen var det knapt politisk mulig for MID å unnlate å reagere. Den rødglødende (i diplomatisk sammenheng) språkbruken i protestnoten som ble overlevert i forbindelse med «Sapfir-2»-saken, vitner om sterk frustrasjon. Det tok likevel ikke lang tid før russiske myndigheter vendte tilbake til den forsonlige linjen. Etter hva vi har kunnet bringe på det rene, har det ikke kommet noen protester mot arrestasjoner av russiske fartøy i vernesonen siden 2012. Totalt er det snakk om seks saker, hvorav fem inntraff etter Russlands anneksjon av Krim. Alle utenom én har blitt løst i sjøen.

Mye har endret seg på overordnet nivå etter 2014, men Arktis er fremdeles et område der Russland satser på samarbeid heller enn konflikt. På sikt ønsker man å få til et samarbeid med vestlige selskaper om offshore petroleumsutvinning, og spenning og episoder i relativ nærhet til petroleumsfeltene vil virke negativt. Generelt er Russland interessert i at havrettsregimet i Arktis oppleves som konfliktforebyggende og velfungerende, selv om man bestrider Norges tolkning av Svalbardtraktaten når det gjelder de maritime sonene rundt Svalbard. Begge deler tilsier at Russland som en hovedlinje i politikken vil ønske å opptre pragmatisk og samarbeidsorientert i nord. 
Samtidig ser det ut til at det går en grense for hvor langt man vil trekke denne pragmatismen. Russland har åpenbart ingen planer om å anerkjenne vernesonen som norsk jurisdiksjonsområde med det første. Snarere tyder signalene som kom fra Lavrov og fra Forsvarsministeriet i 2017, samt uttalelsen i februar 2020 i forbindelse med 100-årsmarkeringen av Svalbardtraktaten, på et økende behov for å demme opp for en "krypende» norsk jurisdiksjon på Svalbard. Dette understøttes av det faktum at den russiske part har valgt å prioritere, og endog trappe opp, patruljevirksomheten i vernesonen, tross landets pressede økonomi de siste årene.

\section{Konfliktfare og konfliktforebygging}

Gitt regionale myndigheters svake stilling og de mange tiltakene for å dempe fiskernes misnøye med norsk håndhevingspraksis anser vi det som lite sannsynlig at regionale eller private aktører vil søke å utfordre den norske Kystvakten i vernesonen. Vi betrakter faren for direkte konfrontasjoner i sonen som liten, men skulle det komme noen slike utspill fra russisk side, vil det antakelig skje på sentralmaktens initiativ eller i det minste med sentralmaktens velsignelse.

Vårt materiale tilsier at det mest sannsynlige utgangspunktet for en alvorlig eskalering av konflikten er en situasjon der russiske oppsynsskip prøver å gripe inn under en norsk inspeksjon/arrestasjon, og at utviklingen deretter kommer ut av kontroll. Dersom mannskaper settes i fare eller - i verste fall - liv går tapt under en slik konfrontasjon, kan russiske myndigheter oppleve press fra opinionen for å svare på opplevd aggresjon. Nasjonalistiske og kraftpatriotiske strømninger fikk som kjent et oppsving etter 2014.

Imidlertid har vi ikke funnet noen oppslag som tyder på at slike episoder har funnet sted i senere år, og dette bekreftes av den norske Kystvakten. Hendelsene som er beskrevet, og som involverte oppsynsskip fra fiskerimyndighetene, skriver seg fra 2008-2011 - en periode da Fiskeribyråets leder markerte seg tydelig i offentligheten som forkjemper for fiskernes interesser.

Patruljevirksomheten i Fiskevernsonen utføres i dag av den russiske Kystvakten, som ligger under FSB/Grensetjenesten. Etatens folk synes ikke å ha noen spesiell lojalitet overfor russiske fiskere, mens de har et svært godt samarbeid med sine norske kollegaer. Derimot har FSB en sterk tradisjon for å se seg selv som nasjonens forsvarere, og enkelte uttalelser kan, som nevnt, tyde på et ønske om å komme på like fot med den norske Kystvakten i vernesonen. Alt i alt vil vi anta at Grensetjenesten vil ha en høy terskel for å gå i direkte konfrontasjon med Kystvakten i sonen. FSB er generelt mer disiplinert enn fiskerietaten. Dessuten er FSB direkte underlagt presidenten, og russisk Arktis-politikk tilsier at landets ledelse ønsker ro i regionen. Her må vi likevel ta et visst forbehold, gitt signalene som er kommet i det siste fra MID og Forsvarsministeriet om frustrasjon over den norske svalbardpolitikken.

God kommunikasjon mellom Kystvakten og russiske oppsynsetater vil være svært viktig fremover, gitt at Russland synes innstilt på å opprettholde sitt nærvær i vernesonen. Beroligende tiltak, som løsning av saker i sjøen, har minsket faren for eskalering. 
Harmonisering av fiskerireglene har også vært svært viktig, men her har partene møtt veggen når det gjelder det viktigste gjenstående punktet: utkast av fisk. Fra russisk hold har det kommet påstander om at norsk part trenerer arbeidet med harmonisering av utkastreglene og ikke følger opp russisk vilje til samarbeid (Sennikov, 2014; Potasjov, 2016). Dersom det fortsatt viser seg umulig å nå frem til et omforent syn, er det desto viktigere at man fortsetter å arbeide aktivt med informasjonstiltak, teknologi med mer som kan få ned omfanget av utkast i begge land. Mistankene om at norske reguleringer utformes for å ha noe å «ta» russiske fiskere for, er dessverre stadig utbredt, og det kreves langsiktig innsats for å komme slike oppfatninger til livs.

Spesielt interessant er det å se på hvilke overordnede faktorer som fremmer suksess i samarbeidet med Russland. Flere studier fremhevet betydningen av kontakt og dialog for å unngå konflikteskalering og krisesituasjoner. ${ }^{28}$ Som Østhagen (2018) viser, er det tett dialog mellom den norske og den russiske kystvakten i form av regelmessige øvelser i Barentshavet, årlige utvekslinger av fiskeriinspektører og personell mellom hovedkvarterene samt deling av relevant informasjon ved behov. Selv om Ukraina-konflikten i 2014 medførte noen begrensinger, er dialogen mer eller mindre opprettholdt (Østhagen, 2016, 2020, s. 53). En annen viktig arena for dialog er den blandete norsk-russiske fiskerikommisjonen, der blant annet Kystvakten deltar. I tillegg er arenaer som det arktiske kystvaktforumet etablert, med fokus på praktisk multilateralt samarbeid.

Et moment som tillegges spesiell vekt, særlig av Kystvakten selv, men også i litteraturen om samarbeid i Barentshavet, er den personlige kontakten mellom mennesker, både på embetsnivå og på det operasionelle nivået (Hønneland \& Jørgensen, 2015). Her handler det ikke bare om møtepunkter, men også om kontinuitet. Ved å beholde de samme menneskene i nøkkelroller klarer Kystvakten å bygge opp personlige forhold over flere år. Dette bidrar til utvikling av tillit og til at det dannes et interessefellesskap; en gruppe mennesker som tilnærmer seg det samme problemet (fiskerikonflikt, søk- og redningsoperasjon, oljeutslipp) på lik måte..$^{29}$

Det ligger naturligvis også en kost-nytte-kalkulering til grunn for mye av dette samarbeidet. Bærekraftig forvaltning av felles fiskebestander kommer begge parter til gode. Det samme giør samarbeid om mulige olje- og gassprosjekt i tidligere omstridt område. Kriseberedskap og søk- og redningstjenester er også et felt hvor samarbeid oppnår mer enn hva hvert land er i stand til unilateralt. De grunnleggende interessefellesskapene har dermed stor betydning for at samarbeidet og dialogen opprettholdes og videreutvikles. Her kan også Kystvaktens assistanse til russiske fiskere trekkes frem som en ytterligere positiv dimensjon. Den todelte rollen Kystvakten har, som både håndhever av fiskerireglene og «barmhjertig samaritan»

\footnotetext{
${ }^{28}$ Et mangfold av studier som har sett på norsk-russisk fiskeri- og ressursforvaltning samt kystvaktsamarbeid, påpeker verdien av dette i det norsk-russiske forholdet for øvrig. Se blant annet Hønneland, 2012; Kosmo, 2010; Østhagen, 2016, 2020.

${ }^{29}$ Se for eksempel Hønneland, 1999 og Haas, 1989.
} 
overfor russiske fiskere, er med på å bygge opp under interessefellesskapet og skape godvilje hos motparten.

Det mer overordnete maktforholdet skal heller ikke neglisjeres. Norge er rett nok medlem i NATO, men det er også et relativt lite land sammenlignet med Russland, med en konsekvent utenriks- og sikkerhetspolitisk linje med vekt på kontinuitet, samarbeid og tilstedeværelse. Dette muliggiør et praktisk og operativt samarbeid i nord som ikke går på tvers av Russlands egne ambisjoner som stormakt, verken i Arktis eller for øvrig.

Generelt er Svalbard og vernesonen et område hvor Russland kan ønske å teste og tøye grenser, eventuelt også utfordre Norges håndhevelse av suverene rettigheter innen ressursforvaltningen. Den økte oppmerksomhet rettet mot Svalbard de seneste årene fra Russland, gjennom besøk, tilknytning til militære øvelser, og forskningsstasjoner, kan medføre utfordringer for Norge - og for Kystvakten. Forverringen i forholdet mellom Norge og Russland betyr også at eventuelle situasjoner som kan oppstå i vernesonen, vil tolkes inn i et mer spent sikkerhetspolitisk bilde. Nettopp dette kan være med på å forklare viljen til å unngå slike situasjoner mellom de to landenes kystvakter (Østhagen, 2018).

Det er derimot ikke noe ved disse aspektene som er konstant eller statisk. Et ytterligere bortfall av arenaer for dialog vil kunne endre på både personlige forhold og tilgang til møteplasser. Grunnlaget for felles interesser kan også endre seg. Klimatiske endringer, økonomiske nedgangstider for fiskeriene og kraftig reduserte kvoter har potensial til å utfordre dagens situasjon. Det samme har endringer i maktforhold.

Samtidig har vi i denne studien ikke funnet noe som indikerer at 2014 representerer noe vannskille med hensyn til konfliktnivået i vernesonen. Slik det også var tilfelle i sovjetperioden, synes det som om begge parter har vært opptatt av å skjerme fiskerisamarbeidet mest mulig mot svingninger i de politiske konjunkturene mellom landene. Dette sier noe om den store verdien samarbeidet har for partene. Det underbygger også ideen om at ikke alt som har en sikkerhetspolitisk dimensjon, nødvendigvis blir politisert og satt i en sikkerhetspolitisk sammenheng.

\section{Konklusjon}

I denne artikkelen ønsket vi å vurdere de empiriske endringene som forholdet mellom Norge og Russland har gjennomgått med hensyn på vernesonen rundt Svalbard og den underliggende konflikten som ligger i de to statenes syn på sonen. Vi spurt: Hvilke endringer - om noen - har vi sett i forbindelse med forverringen i det bilaterale forholdet etter 2014? Og hva betyr dette for faren for en eventuell konflikt i dette området?

Oppsummert finner vi at 2014 ikke fremstår som noe vannskille med hensyn til forholdet mellom Norge og Russland i vernesonen. Den store endringen kom da de russiske føderale myndighetene fra og med «Elektron»-saken i 2005 gikk over fra protest til dialog. Siden har Russland lagt seg på en relativt forsonlig linje. Unntaket 
er en kort periode etter arrestasjonen av den russiske tråleren «Sapfir-2» i etterkant av delelinjeavtalen mellom Norge og Russland fra 2010, da store deler av rederinæringen og andre $i$ det russiske nord var i harnisk og krevde handling angående vernesonen. Etter 2011 har hendelser i vernesonen blitt håndtert uten ytterligere eskalering. Dette er derimot ikke en naturtilstand, men en situasjon underbygd av en rekke spesifikke faktorer som kan komme til å endre seg.

\section{Om forfatterne}

Anne-Kristin Jørgensen er seniorforsker ved Fridtjof Nansens institutt i Oslo. Hun er også tilknyttet Universitetet i Tromsø: Norges arktiske universitet. Jørgensen har en cand. polit. fra Universitetet i Oslo og har tidligere arbeidet som Fiskeriråd ved Norges Ambassade i Moskva.

Andreas Østhagen er seniorforsker ved Fridtjof Nansens institutt i Oslo. Han er også tilknyttet Nordområdesenteret ved Nord Universitet i Bodø, en del av lederteamet i The Arctic Institute i Washington DC, og underviser ved Bjørknes Høyskole. Østhagen har en doktorgrad i internasjonal politikk fra University of British Columbia og en mastergrad fra London School of Economics.

\section{Referanser}

Aftenposten. (2005, 22. oktober).Voldsomme utfall mot Norge. Hentet fra https:/www.aftenposten.no/norge/i/ JQny6/Voldsomme-utfall-mot-Norge

Barents Observer. (2017, 19. oktober). Lavrov attacks Norway, says relations on Svalbard should be better. Hentet fra https://thebarentsobserver.com/en/arctic/2017/10/lavrov-attacks-norway-over-svalbard

BBTU (Det føderale fiskeribyråets territoriale avdeling for Barentshavet og Kvitsjøen). (2016, 17 august). Arest sudna M-0239 'Mel'kart' v rajone arkhipelaga Sjpitsbergen (Arrestasjonen av fartøyet M-0239 «Mel'kart» i området ved øygruppen Svalbard). Hentet fra http://bbtu.ru/index.php/novosti/718-arestsudna-m-0239-melkart-beregovoj-okhrany-norvegii-v-rajone-arkhipelaga-shpitsbergen.html

B-port. (2012, 26. oktober). Pogranitsjniki patrulirujut u Sjpitsbergena' (Grensetjenesten patruljerer ved Svalbard). Hentet fra https://b-port.com/news/90535

Bekjasjev, K. (2006). Greier Russland å beskytte sine rettigheter i fiskevernsonen rundt Svalbard? (opprinnelig russisk tittel ikke kjent). Morskoe pravo i praktika (Havrett og praksis), 3(11).

Bekjasjev, K. (2009). Sovremennyj mezjdunarodno-pravovoj status arkhipelaga Sipitsbergen (Øygruppen Svalbards internasjonale juridiske status i dag). Lex Russica, 6, 1469-1477. Hentet fra http://portal-msal. ru/netcat_files/493/657/lexrussica-6-2009-19062.pdf

Bercovitch, J., Kremenyuk, V. \& Zartman, I. W. (2009). Introduction: The nature of conflict and conflict resolution. I J. Bercovitch, V. Kremenyuk \& I. W. Zartman (Red.), The Sage handbook of conflict resolution (s. 1-11). London: Sage Publications. Hentet fra https://doi.org/10.4135/9780857024701

Boldysjeva, V. D. (2011, 22. oktober). Bitva za Sjpitsbergen ili razgranitsjenie jurisdiktsii mezjdu Rossiej i Norvegiej (Kamp om Svalbard eller avgrensning av jurisdiksjonen mellom Russland og Norge). Korabel.ru. Hentetfrahttps://www.korabel.ru/news/comments/bitva_za_shpitsbergen_ili_razgranichenie_yurisdiktsiy_ mezhdu_norvegiey_i_rf_v_more.html

Bruusgaard, K. V. (2006). Fiskerikonflikter $i$ Barentshavet - potensial for eskalering? FFI/Rapport-2006/03167. Oslo: FFI. Hentet fra https://fhs.brage.unit.no/fhs-xmlui/handle/11250/2444396

Denisenko, E. (2009).V svoem prave (I sin rett), Ekspert Severo-Zapad, 47 (444). Hentet fra https://expert.ru/ northwest/2009/47/arktika/

Den blandete norsk-russiske fiskerikommisjon. (2009). Protokoll for den 38. sesjon. Hentet fra http://www. jointfish.com/OM-FISKERIKOMMISJONEN/PROTOKOLLER.html 


\section{Anne-Kristin Førgensen og Andreas Østhagen}

Etterretningstjenesten. (2018). Fokus 2018. Etterretningstjenestens vurdering av aktuelle sikkerhetsutfordringer. Hentet fra https:/forsvaret.no/fakta_/ForsvaretDocuments/Fokus2018_bokmaal_oppslag_godkjent.pdf

Fermann, G. \& Inderberg, T. H. (2015). Norway and the 2005 Elektron Affair: Conflict of competencies and competent realpolitik, I T. G. Jakobsen (Red.), War: An introduction to theories and research on collective violence (s. 373-402). New York: Nova Science.

Fiskeribladet. (2017, 26. mai). Tolker Remøy-saken som hevn. Hentet fra https://www.nrk.no/mr/tolker-remoysaken-som-hevn-1.13534010

Fløistad, B. (2008), Svalbard-traktaten - ulike oppfatninger om traktatens anvendelsesområde, Stortingets utredningsseksjon, Perspektiv 05/08. Hentet fra https://www.stortinget.no/Global/pdf/Utredning/Perspektiv 08_05.pdf

Forskningsrådet. (2010, 4. november). Vil bidra til ro og stabilitet. Hentet 10. februar fra https://www. forskningsradet.no/prognett-geopolitikk-nord/Nyheter/_Vil_bidra_til_ro_og_stabilitet/1253962773266 \&lang=no (Siden er nå tatt ned og linken fungerer ikke lenger).

FSB. (2016, u.d.). Nelegal'naja migratsija i konflikty v mire menjajut situatsiju na granitse (Illegal migrasjon og konflikter i verden endrer situasjonen ved grensen). Hentet fra http://ps.fsb.ru/smi/appearance/detail. htm\%21id\%3D10321180\%40fsbAppearance.html

Grønning, R. (2017, 20. november). Norsk svalbardpolitikk - hvor står den internasjonalt? Den norske Atlanterhavskomité. Hentet fra http://www.atlanterhavskomiteen.no/post/14468500/norsk-svalbardpolitikk-hvor-star-den-internasjonalt

Haas, P. M. (1989). Do regimes matter? Epistemic communities and Mediterranean pollution control. International Organization 43(3), 377-403.

Hønneland, G. (1999). Co-management and communities in the Barents Sea fisheries. Human Organization 58(4), 397-404.

Hønneland, G. (2012). Norsk-russisk miljø- og ressursforvaltning i Nordområdene, Nordlit 16(1), $79-87$. Hentet fra https://septentrio.uit.no/index.php/nordlit/article/view/2303

Hønneland, G. (2013). Hvordan skal Putin ta Barentshavet tilbake? Bergen: Fagbokforlaget.

Hønneland, G. (2016). Russia and the Arctic: Environment, identity and foreign policy. London: I. B. Tauris.

Hønneland, G. \& Jørgensen, A.-K. (2015). Kompromisskulturen i Barentshavet. IT. Heier \& A. Kjølberg (Red.), Norge og Russland: Sikkerhetspolitiske utfordringer i Nordområdene (s. 57-68). Oslo: Universitetsforlaget.

Ims, M. (2013). Russiske oppfatninger om delelinjeavtalen i Barentshavet, masteroppgave, Universitetet i Tromsø. Hentet fra https://munin.uit.no/handle/10037/5229

Jørgensen, J. H. (2010). Russisk svalbardpolitikk. Trondheim: Tapir Akademisk Forlag.

Kalasjnikov, L. (2011). Rossija gotova podarit' Norvegii sotni tysjatsj kvadratnykh kilometrov Barentseva morja (Russland er rede til å gi Norge hundretusenvis av kvadratkilometer i Barentshavet), Svobodnaja Pressa, 24. mars 2011. Hentet fra https://svpressa.ru/all/article/40913/

Kommersant. (2017, 03. oktober). Geopolitika v pomosjtsj snabzjenija (Geopolitikken til hjelp for forsyningene). Hentet fra https://www.kommersant.ru/doc/3428044

Kosmo, S. (2010). Kystvaktsamarbeidet Norge-Russland. En fortsettelse av politikken med andre midler? Masteroppgave, Forsvarets Stabsskole. Hentet fra https://fhs.brage.unit.no/fhs-xmlui/bitstream/handle/ $11250 / 99900 /$ Kosmo $\% 2 c \% 20$ Svein.pdf?sequence=1\&isAllowed=y

Kyst og Fjord. (2012, 24. juli). Njet til kystvakt-samarbeid. Hentet fra https:/www.kystogfjord.no/nyheter/ forsiden/Njet-til-kystvakt-samarbeid

Mitchell, C. R. (1981). Peacemaking and the consultants role. Westmead, UK: Gower Publishing.

Moe, A., Fjærtoft, D. \& Øverland, I. (2011). Space and timing: Why was the Barents Sea delimitation dispute resolved in 2010? Polar Geography, 34(3), 145-62.

Nevskoe vremja. (2011, 27. oktober). Norvezjskie rybaki privatizirovali Sjpitsbergen (Norske fiskere har privatisert Svalbard). Hentet fra https:/nvspb.ru/2011/10/27/norvejskie-rybaki-privatizirovali-shpicbergen- 46732

Nezavisimoe voennoe obozrenie. (1999, 10. november). Tikhaja vojna vokrug Sjpitsbergena (Den stille krigen om Svalbard). Hentet fra http://nvo.ng.ru/world/1999-11-10/6_shpitsbergen.html

NRK. (2016, 30. juni). Oljestrid ved Svalbard kan ende i internasjonal domstol. Hentet fra https://www.nrk.no/ norge/oljestrid-ved-svalbard-kan-ende-i-internasjonal-domstol-1.12987825

Osen, G. (2004, 27. august). Norsk suverenitet og myndighetsutøvelse. Sjømaktseminar 9(2004), Ulvik. Hentet fra http://www.sms1835.no/arkiv/sjømaktseminar/Nr9

Pedersen, T. (2009). Endringer i internasjonal svalbardpolitikk, Internasjonal politikk, 67(1), 31-44. Hentet fra https:/www.idunn.no/file/pdf/33204989/ip_2009_01_pdf.pdf 
Pedersen, T. (2016). Gruvedrift og sikkerhetspolitikk. Ottar, 310(2), 3-9. Hentet fra https://uit.no/Content/ $535804 /$ cache $=20172009095253 /$ pederserngruve.pdf

Portsel, A. K. (2012). Rossija ostaetsya na Sipitsbergene (Russland forblir på Svalbard), Arktika i Sever, 9, 1-20. Hentet fra https://cyberleninka.ru/article/n/rossiya-ostaetsya-na-shpitsbergene

Potasjov, V. (2016, 5. april). Konets rybnym konfliktam polozjat edinye 'pravila igry'? (Vil «like spilleregler» få en slutt på fiskerikonfliktene? Intervju med Vjatsjeslav Zilanov). Tsjernika. Hentet fra https://mustoi.ru/ konec-rybnym-konfliktam-polozhat-edinye-pravila-igry/

Rowe, L. (2018). Fornuft og følelser: Norge og Russland etter Krim, Nordisk Østforum, 32, 1-20.

Sennikov, S. A. (2014). Mezjdunarodnye dogovory Rossijskoj Federatsii kak pravovaja osnova rybolovstva v morskom rajone arkhipelaga Sjpitsbergen (Den russiske føderasjons internasjonale avtaler som juridisk grunnlag for fiskeriene i det marine området rundt øygruppen Svalbard), Eurasian Law fournal, 7(74), 88-91.

Shut, D. (2012). Hvilken effekt hadde sentraliseringen $i$ Russland på fiskerisamarbeidet med Norge?, masteroppgave, Universitetet i Oslo. Hentet fra https:/www.duo.uio.no/bitstream/handle/10852/34411/1/Shut-Master.pdf

Skram, A.-I. (2017). Alltid til stede: Kystvakten 1997-2017. Bergen: Fagbokforlaget.

Timtsjenko, L. (1992). Sjpitsbergen: Istorija $i$ sovremennost (Svalbard: historie og nåtid). Kharkov: Osnova.

Troms og Finnmark statsadvokatembeter og Rogaland statsadvokatembeter. (2014). Midlertidige retningslinjer for etterforskning og påtalehåndtering av fiskerisaker mens fartøyet er i sjøen.

Tsypalov, V. (2009). Natsional'nye interesy Rossii na arkhipelage Shpitsbergen (Russlands nasjonale interesser på øygruppen Svalbard), Analititsjeskij vestnik SF FS RF, 12(379).

TV21. (2017, 30. januar). V Murmansk prisjel pogranitsjnyj korabl' u kotoroga net analogov v mire (Det har kommet et skip til Murmansk som ikke har sin like i verden). Hentet fra https://www.tv21.ru/ news/2017/01/30/v-murmansk-prishel-pogranichnyy-korabl-u-kotorogo-net-analogov-v-mire

Ura.news (2017, 18. desember). Glava Arktitsjeskogo soveta prizval vernut' Sjpitsbergen Rossii (Arktisrådets leder oppfordret til å tilbakeføre Svalbard til Russland). Hentet fra https://ura.news/news/1052317030

Vesti (2005, 18. oktober). Sergej Lavrov: nuzjny peregovory po statusu vod vozle Sjpitsbergena (Sergej Lavrov: Det er behov for drøftinger om statusen til farvannene ved Svalbard). Hentet fra http://www.vesti.ru/doc. html?id=69975

Vylegzhanin, A. \& Zilanov, V. (2007), Spitsbergen: legal regime of adjacent marine areas, Utrecht, NL: Eleven International Publishing.

Zilanov, V. (2016). Smesjannaja sovetsko/rossijsko-norvezjskaja kommissija po rybolovstvu: ot istokov tsjerez doverie $\mathrm{k}$ budusjemu (Den sovjetisk/russisk-norske fiskerikommisjon: fra opprinnelsen gjennom tillit til fremtiden), Voprosy rybolovstva, 17(4), 460-483.

Zilanov, V. (2018). Mister Russland Arktis? Oslo:Vidarforlaget AS. (Utgitt 2013 med tittel: Rossija terjaet Arktiku?. Moskva: Algoritm.)

Østhagen, A. (2016). High North, Low politics - maritime cooperation with Russia in the Arctic. Arctic Review on Law and Politics, 7(1), 83-100.

Østhagen, A. (2018). Managing conflict at sea: The case of Norway and Russia in the Svalbard Zone. Arctic Review on Law and Politics, 9, 100-123.

Østhagen, A. (2020). Coast Guards and Ocean Politics in the Arctic. Singapore: Palgrave Macmillan.

Østhagen, A. \& Raspotnik, A. (2019). Why is the European Union challenging Norway over snow crab? Svalbard, special interests, and Arctic governance. Ocean Development and International Law, 50(2-3), 190-208.

Åtland, K. (2016). Myndighetsutøver, ressursforvalter og livredder - den russiske kystvakten i støpeskjeen. Nordisk Østforum, 30(1), 38-54. Hentet fra https://doi.org/10.17585/nof.v30.390

\section{Abstract in English \\ Safeguarding Norwegian Rights around Svalbard: Russian Perceptions and Reactions Svalbard and the maritime zone around the Arctic Archipelago are central to the bilateral relationship between Norway and Russia, both in terms of economic and security concerns. Since 1977, a dispute between the countries has concerned Norway's right to assert sovereignty in these waters. What are Russian perceptions of Norwegian sovereignty enforcement in the Fisheries Protection Zone (FPZ)? How have perceptions and reactions evolved since}


the turn of the millennium? What changes - if any - do we see in connection with the deterioration in the bilateral relationship after 2014? And what does this mean for the danger of a possible conflict in this area? In summary, we find that 2014 does not appear to be a watershed with respect to the relationship between Norway and Russia in the FPZ around Svalbard. The change came when Russian central authorities after the Elektron-case in 2005 switched from protest to dialogue. Since then, a relatively conciliatory line has been emphasized regarding this dispute. The exception is a short period after the arrest of the Russian trawler Sapfir-2 following the 2010 Norway-Russia Delimitation Agreement, when large parts of the fishing industry and other regional actors in the Russian north were in harness and demanded action. After 2011, incidents in the FPZ have been handled without further escalation, although this is by no means a state of nature, but a situation underpinned by a number of specific factors that could be subject to change.

Keywords: Fisheries Protection Zone • Svalbard • Russia • Coast Guard • Arctic 